\title{
Influence of extraction method on protein profile of soybeans
}

\author{
Milica Ž. Pavlićević, Slađana P. Stanojević, Biljana V. Vucelić-Radović \\ University of Belgrade, Faculty of Agriculture, Institute for Food technology and biochemistry, Department of Chemistry \\ and Biochemistry, Belgrade, Serbia
}

\begin{abstract}
Comparison between protein profiles of soybean obtained by commonly used methods of extraction (Tris buffer and Tris-urea buffer) with methods used for extraction of plant proteins for 2D PAGE analysis (direct solubilization in IEF buffer, acetone extraction, phenol extraction, extraction with urea solubilization buffer and thiourea-urea extraction) was investigated. 2D profiles of samples extracted directly in IEF buffer, in urea solubilization buffer and in acetone were characterized with low number of spots. Analysis of 2D PAGE profiles of Tris buffer and Tris-urea buffer extracts showed high degree of horizontal and vertical streaking. Thiourea-urea extraction gave a higher number of less intense protein spots than phenol extraction. The method of choice, due to a large number of intense spots, would be phenol extraction.
\end{abstract}

Keywords: soybean proteins; 2D PAGE analysis; extraction; densitometry; isoelectric focusing.

\section{SCIENTIFIC PAPER}

UDC 633.34:664:66.061.3

Hem. Ind. 67 (4) 687-694 (2013)

doi: 10.2298/HEMIND120919115P

Available online at the Journal website: http://www.ache.org.rs/HI/

Soy seed (Glycine max L.) contains, on average, 35$40 \%$ proteins, $18-22 \%$ oils, $5-6 \%$ oligosaccharides and $5 \%$ of fiber [1]. Because of high protein content (with a high ratio of essential amino acids [2]), as well as high concentration of antioxidants [3] and unsaturated fatty acids [4], soy has been recognized as functional food. Modification in ratio and/or structure of soybean proteins has an important influence on technological functional properties of soybean products [5-8].

There are two major types of soybean proteins: 115 (glycinin) and 7S ( $\beta$-conglycinin) [8]. Glycinin (MW: 320000-360000) possesses a hexameric structure with three basic polypeptides (MW: 18000-20000, pl 6.5-8.5) and three acidic polypeptides (MW 36000-40000, pl 4.8-5.5) linked by a disulfide bond. Conglycinin (MW: 140000-180000) has a trimeric form consisting of an $\alpha$ subunit (MW: 76000, pl 4.9), $\alpha^{\prime}$ subunit (MW: 70000, pl 5.2 ) and $\beta$ subunit (MW: 53000 , pl 6.0) aggregated by non-covalent interaction. It is known that the $\mathrm{pH}$ and ionic strength of the extraction solution greatly influence isoforms of proteins [5-8] present in the extract. The influence of isoforms composition on important technological characteristics of soybean proteins, such as protein solubility, gelling properties, the ability to form stable emulsions and foams is well documented [6-9]. Commonly, proteins of soybean seed are extracted either by Tris-HCl buffer as suggested by Than and Shibasaki [10], or by distilled water with subsequent enforcement of ionic strength and addition of denatu-

Correspondence: B.V. Vucelić-Radović, Department of Chemistry and Biochemistry, Institute for Food technology and biochemistry, Faculty of Agriculture, University of Belgrade, Nemanjina 6, 11030 Belgrade, Serbia.

E-mail: bvucelic@agrif.bg.ac.rs

Paper received: 19 September, 2012

Paper accepted: 29 November, 2012 rant [11]. However, for extraction of plant proteins for 2D PAGE analysis, the typically used methods are phenol extraction and extraction with TCA-acetone $[12,13]$.

Several papers have been published in which comparison between different extraction methods of plant proteins had been conducted [14,15]. Furthermore, compatibility of such extraction methods for subsequent analysis by mass spectrometry has also been examined $[16,17]$.

However, such examinations mainly employed methods of extraction developed specifically for 2D PAGE analysis. So far, no attempt was done to analyze soybean Tris- $\mathrm{HCl}$ or Tris-urea buffer protein extracts by two-dimensional electrophoresis.

SDS-PAGE analysis is often used as a screening method for soybean protein samples to be examined by 2D PAGE. The wide application of SDS PAGE analysis as a screening method can be explained by the fact that there is a variety of literature data on main protein fractions and proteins of soybeans analysis employing this method. Thus, the positions of subunits of major storage proteins in the gel are very well characterized. Since extraction with Tris- $\mathrm{HCl}$ is a method of choice when soybean extract is analyzed by SDS-PAGE, it would be useful to know whether Tris- $\mathrm{HCl}$ extract of soybean proteins could be used for both types of analyses. This could help in avoiding either loss of proteins in steps of precipitation and resolubilization in other buffer or loss of the plant material when two different extractions are needed. In fact, this would allow the analysis of heterogeneous soy protein extracts without previous separation of major protein fractions. These, also, could be potentially beneficial for industry because it would allow the same extract to be analyzed by both SDS-PAGE and 2D electrophoresis. Thus, by analysis of single extract it would be possible to obtain large num- 
ber of data. Also, such analyses would be faster and less expensive then analysis of extracts obtained by different extraction methods.

Thus, the aim of this work was to examine if Tris- $\mathrm{HCl}$ buffer or Tris-urea buffer extraction of soybean proteins could be used for 2D PAGE analysis and to compare protein profiles of these extracts with protein profiles of extracts obtained by usual methods of plant protein extraction for proteomic analysis (phenol extraction, extraction with urea solubilization buffer, direct extraction in IEF buffer, acetone extraction, thiourea-urea extraction).

\section{MATERIALS AND METHODS}

Plant materials. Soybean seed (Glycine max L.) of cultivar Novosađanka were provided by the Institute for Field and Vegetable Crops (Novi Sad, Serbia).

Chemicals. All chemicals were p.a. grade. Tris, acrylamide, bis-acrylamide, ammonium persulfate, thiourea, urea, EDTA, sucrose, methanol, ammonium acetate, ethanol, phosphoric acid, $n$-hexane, bromophenol blue (BPB), Sodium dodecyl sulfate (SDS), beef serum protein (BSA), Coomassie brilliant blue (CBB) G250 and CBB R250 were purchased from Merck (Germany). Tetramethylethylenediamine (TEMED) and phenol were purchased from Sigma (St. Louis, MO, USA). CHAPS was purchased from Serva (Heidelberg, Germany). Dithiothreitol (DTT), iodoacetamide, ampholytes ( $\mathrm{pH} 3-10)$ overlaying agarose, immobilized $\mathrm{pH}$ gradient (IPG) strips (ReadyStrip) (pH 3-6, $\mathrm{pH} 3-10)$ were purchased from Bio-Rad (Hercules, CA, USA).

Determination of proteins: Concentration of proteins was determined according to the method of Bradford [18]. For determination of proteins, a standard curve was made by mixing $100 \mu \mathrm{l}$ of sample of known protein concentration with $5 \mathrm{ml}$ of dye (Coomassie Brilliant Blue G-250). As a standard for construction of standard curve, BSA was used. Concentration of proteins in samples was determined in the same manner as described for construction of standard curve. Quantification was done by spectroscopic measurement of adsorption maximum of bonded dye at $595 \mathrm{~nm}$.

Isoelectric focusing. Prior to isoelectric focusing, strip was rehydrated with sample for $12 \mathrm{~h}$ at room temperature. Isoelectric focusing was performed in a Protean IEF Cell (Bio-Rad) using $7 \mathrm{~cm}$ strips (pH 3-6 and 3-10) under the following conditions: S01-250V, 15 min; S02-4000V, rapid; S03-10000Vh, rapid; focusing temperature, $20^{\circ} \mathrm{C}$. Extracts of each extraction method were analyzed using strips of $\mathrm{pH}$ range 3-6 and 3-10. Total protein content per strip was $100 \mu \mathrm{g}$. Each analysis was performed in duplicate.

Second dimension. Prior to placing strips on top of the gels, strips were equilibrated in equilibration buffer 1 (0,375 M Tris- $\mathrm{HCl}$ (pH 8.8), $6 \mathrm{M}$ urea, $20 \%$ glycerol,
$2 \%$ SDS, $0.002 \%$ bromophenol blue, $2 \%(\mathrm{w} / \mathrm{v}) \mathrm{DTT})$ for $15 \mathrm{~min}$ and equilibration buffer $2(0,375 \mathrm{M}$ Tris $-\mathrm{HCl}(\mathrm{pH}$ 8.8), $6 \mathrm{M}$ urea, $20 \%$ glycerol, $2 \%$ SDS, $0.002 \%$ bromophenol blue, $2.5 \%$ iodoacetamide) for $20 \mathrm{~min}$. Then, the strips were placed for $5 \mathrm{~min}$ in the electrode buffer (0.25 M Tris base, 1.92 M glycine, 1\% SDS) and placed on top of the gels. After placing strips on gels, strips were sealed with an overlaying agarose solution $(0.25$ $\mathrm{M}$ Tris base, $1.92 \mathrm{M}$ glycine, 1\% SDS, 0.5\% agarose, $0.002 \%$ bromophenol blue). SDS PAGE was done in Mini Protean Tetra Cell (Bio-Rad) using Laemmli method [19] on $12 \%$ acrylamide gels. During the run, the voltage was constant ( $250 \mathrm{~V}$ ). Gels were visualized by mixing for $1 \mathrm{~h}$ at room temperature in dye solution $(0.001 \%$ (w/v) CBB G250, 40\% ethanol, 10\% acetic acid, $10 \%(\mathrm{w} / \mathrm{v}) \mathrm{TCA})$. The gels were destained for $24 \mathrm{~h}$ in a solution containing $40 \%$ ethanol, $10 \%$ acetic acid.

Acetone extraction. Samples were prepared by grinding previously frozen (with liquid nitrogen) seeds with mortar and pestle. $500 \mathrm{mg}$ of sample was vortexed with $2.5 \mathrm{ml}$ of $100 \%$ acetone. Extraction was performed at $-20{ }^{\circ} \mathrm{C}$ for $2 \mathrm{~h}$. The pellet was recovered by centrifugation (10 $\mathrm{min}, 13500 \mathrm{rpm}$ ). Then, the pellet was washed twice by resuspending in $0.5 \mathrm{ml} 70 \%$ acetone and centrifuged (10 min, $13500 \mathrm{rpm}$ ). The pellet was dried at room temperature and dissolved in IEF buffer (8 M urea, 2\% (w/v) CHAPS, $50 \mathrm{mM} \mathrm{DTT,} \mathrm{0.2 \%}$ $(\mathrm{w} / \mathrm{v})$ ampholytes $\mathrm{pH} 3-10,0.01 \%(\mathrm{w} / \mathrm{v}) \mathrm{BPB})$, by vortexing (10 $\mathrm{min}$ ) and sonication (1 h).

Phenol extraction. Phenol extraction was done by method of Hurkman and Tanaka [20], with modification in content of IEF buffer (higher concentration of urea and CHAPS and absence of thiourea). $1 \mathrm{~g}$ of frozen (in liquid nitrogen) soybean seeds were ground using mortar and pestle. The sample was then extracted with 1:1 ratio of buffered phenol and extraction buffer $(2.5 \mathrm{ml}$ of phenol buffered with Tris- $\mathrm{HCl}(\mathrm{pH} 8.8)$ and $2.5 \mathrm{ml}$ of extraction solution (0.1 M Tris- $\mathrm{HCl}(\mathrm{pH} 8.8), 10 \mathrm{mM}$ EDTA, 0.4\% 2-mercaptoethanol, $0.9 \mathrm{M}$ sucrose). The extract was vortexed for $5 \mathrm{~min}$ and sonicated for 30 $\min$ at $4{ }^{\circ} \mathrm{C}$. Then the extract was centrifuged twice for $15 \mathrm{~min}$ at $13500 \mathrm{rpm}$ at $4{ }^{\circ} \mathrm{C}$. The upper, phenolic phase was separated and proteins were precipitated by adding ice cold $0.1 \mathrm{M}$ ammonium acetate in $100 \%$ methanol in ratio 5:1. The extract was vortexed and left to precipitate overnight at $-20{ }^{\circ} \mathrm{C}$. The precipitate was obtained by centrifugation (twice at $14000 \mathrm{rpm}, 20$ $\mathrm{min}, 4^{\circ} \mathrm{C}$ ). Pellet was washed with cold solution of 0.1 $\mathrm{M}$ ammonium acetate in methanol (twice), with $80 \%$ acetone at $-20{ }^{\circ} \mathrm{C}$, and with cold $70 \%$ ethanol. The pellet was dissolved in $1.0 \mathrm{ml}$ of IEF buffer, by incubation for $1 \mathrm{~h}$ at room temperature.

Thiourea-urea extraction. This extraction was carried out as described by Herman et al. [21]. Sample was prepared in similar manner as for acetone and phenol 
extraction, with difference that sample for thioureaurea extraction was further defatted twice with hexane (hexane to sample ratio 20:1, time $1 \mathrm{~h}$, temperature 60 ${ }^{\circ} \mathrm{C}$ ) and dried at room temperature. $100 \mathrm{mg}$ of seed powder was vortexed with $1.5 \mathrm{ml}$ of extraction buffer (5 M urea, $2 \mathrm{M}$ thiourea, 4\% (w/v) CHAPS, $65 \mathrm{mM}$ DTT, $0.8 \%(\mathrm{w} / \mathrm{v})$ ampholytes $(\mathrm{pH} 3-10))$ for $5 \mathrm{~min}$ at room temperature. The supernatant was collected by centrifugation (13500 rpm, $10 \mathrm{~min}$ ).

Direct extraction in IEF buffer. Modified method by Gallardo et al. [22] was used for this extraction. The modification included difference in content of IEF buffer (lower concentration of CHAPS and ampholytes $(\mathrm{pH}$ 3-10), higher concentration of DTT and absence of EDTA and Tris) and usage of sonication for extraction. The sample was prepared as described for acetone and phenol extraction. $100 \mathrm{mg}$ of sample was extracted with $600 \mu \mathrm{l}$ of IEF buffer at room temperature. Extraction was done by vortexing ( $15 \mathrm{~min}$ ) and sonication (45 $\mathrm{min}$ ). Then, the extract was centrifuged (twice for 15 min at $13500 \mathrm{rpm}$ ) and the supernatant was collected.

Extraction with urea solubilization buffer. This procedure was suggested by BerkIman et al. [22]. The original procedure was modified in the sense that the ratio extraction buffer: sample was twice as high and the sonication time was extended to $45 \mathrm{~min}$. The sample was prepared as described for acetone, phenol and direct IEF extraction. $100 \mathrm{mg}$ of sample was extracted with $600 \mu$ l urea solubilization buffer (8 M urea, 4\% CHAPS, $2 \%$ ampholyte ( $\mathrm{pH} 3-10)$. Extraction was done by vortexing $(5 \mathrm{~min}$ ) and sonication ( $45 \mathrm{~min}$ ) at room temperature. The sample was then centrifuged (15 min, $13500 \mathrm{rpm}$ ) and the supernatant was collected.

Tris- $\mathrm{HCl}$ buffer extraction. Extraction was preformed according to the method of Than and Shibasaki [10]. Soybean seeds were ground into powder and $100 \mathrm{mg}$ of powder was defatted with $2 \mathrm{ml}$ of hexane for $1 \mathrm{~h}$ at $60^{\circ} \mathrm{C}$. The sample was then dried at room temperature and dried sample was extracted with $0.03 \mathrm{M}$ Tris- $\mathrm{HCl}$ buffer pH8.0 with 0,01 $\mathrm{M} \beta$-mercaptoethanol for $1 \mathrm{~h}$ at room temperature. Pellet was removed by centrifugation (15 min, $13500 \mathrm{rpm}$ ). The supernatant was diluted with IEF buffer, so that the final concentration of proteins was $1 \mu \mathrm{g} / \mu \mathrm{l}$.

Tris-urea buffer extraction. Modified procedure of Yagasaki et al. [10] was carried out. Time of extraction was prolonged (from 3 to $15 \mathrm{~min}$ ). Soybean seed was defatted as explained for Tris- $\mathrm{HCl}$ buffer extraction. $500 \mathrm{mg}$ of defatted sample was homogenized with $2 \mathrm{ml}$ of distilled water for $15 \mathrm{~min}$ at room temperature. Supernatant was obtained by centrifuging (15 min, $13500 \mathrm{rpm}$ ). Proteins from $20 \mu \mathrm{l}$ of supernatant were re-extracted with $160 \mu$ of Tris-urea buffer $(0.05 \mathrm{M}$ Tris- $\mathrm{HCl}$ pH 8.0, $0.2 \%$ SDS, $5 \mathrm{M}$ urea). $1 \mathrm{~h}$ before isoelectric focusing, $20 \mu \mathrm{l}$ of $\beta$-mercaptoethanol was added to the extract. The extract was then diluted with IEF buffer to a final protein concentration of $1 \mu \mathrm{g} / \mu \mathrm{l}$.

Densitometric analysis and determination of molecular weights. Densitometric analysis of spots in 2D gels, as well as determination of molecular weights of proteins under spots, was done using SigmaGel, version 1.1, software (Jandel Scientific, USA). 2D SDS PAGE standard for determination of molecular weight of spots was purchased from Bio Rad (Hercules, CA, USA) (MW: 76, 66.2, 36, 31, 21.5, 17.5, pl 4.5-8.5).

\section{RESULTS}

2D profiles of soybean proteins obtained by different extraction method were each determined in two $\mathrm{pH}$ regions: 3-10 (Figure 1 ) and 3-6 (Figure 2).

Due to the initial charge of reagents used for extraction or produced charge of extracts (as a consequence of either $\mathrm{pH}$ range of strips or oxido-reduction reaction) Tris- $\mathrm{HCl}$ and Tri-urea buffer extracts were characterized by time-consuming isoelectric focusing step. This effect was prominent in the case of Tris- $\mathrm{HCl}$ extracts. Isoelectric focusing of these samples took as long as $12 \mathrm{~h}$ in comparison to focusing of phenol extract that took only $3 \mathrm{~h}$. These in turn caused visible horizontal streaking.

In order to show differences in one-dimensional profiles of soybean proteins obtained by different extraction methods, the results of SDS PAGE analysis of these samples are presented in Figure 3.

High concentrations of lipids might have caused the appearance of diffuse bands in electrophoregrams of some extracts (especially evident for acetone extract), making densitometric analysis of such sample unreliable.

The usefulness of different extraction methods in analysis of soybean proteins was also assessed based on the number of spots and spot intensity in particular $\mathrm{pH}$ range (Tables 1 and 2). Such analysis could help the determination of amounts of both total proteins and particular protein isoforms present on precise $\mathrm{pH}$. Thus, it would be possible to deduce the influence of ratio of major protein fractions and/or concentration of low abundant proteins on their functional properties.

\section{DISCUSSION}

Acetone extraction is a fast method that efficiently removes salts, sugars and some lipids and concentrates proteins [12]. However, the produced pellet was of low solubility, as has been reported by Thiellement et al. [13] and many of the lipids of higher polarity, as well as phenolic compounds remained as contaminants (Figure 3, C-2). These lipids interfered with isoelectric focusing, thus causing broadening of bands on strips and subsequent horizontal streaking (Figures $1 \mathrm{~B}$ and $2 \mathrm{~B}$ ). Also, 

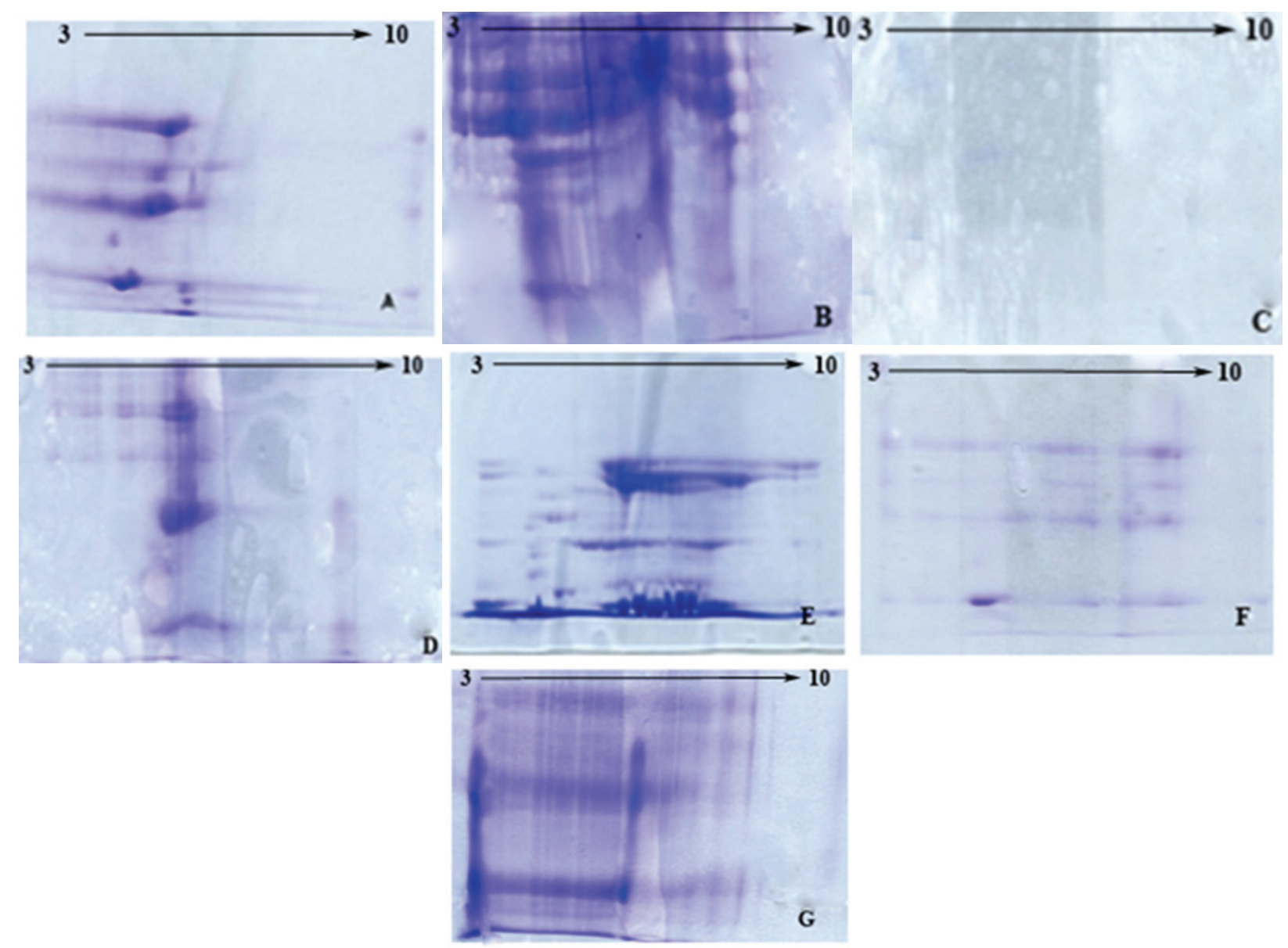

Figure 1. Protein profiles of soybean seed proteins extracted by different extraction methods in $\mathrm{pH}$ range 3-10; A) phenol extraction, $B$ ) acetone extraction, C) urea solubilization buffer extraction, $D$ ) direct extraction in IEF buffer, E) thiourea-urea extraction, F) extraction with Tris-HCl buffer, G) extraction with Tris-urea buffer.

higher rehydratation volumes were necessary because of a low final content of protein $(1.5 \mathrm{mg} / \mathrm{ml})$. These could have also led to a loss of less abundant proteins. Vertical streaking could be explained by prolonged time necessary for solubilization of the pellet. Also, it is possible that the room temperature used during the solubilization step favored hydrophobic interactions and formation of complexes, thus leaving sample only partially solubilized. The lack of clearly defined spots affected the quality of densitometric measurements, but it was evident that the intensity of spots (Table 1) was around $20 \%$ lower than that of thiourea-urea extraction and for $30 \%$ lower than that of phenol extraction. The analysis of molecular weights distribution also proved that, although in the same range as in the other extraction methods, a smaller number of spots per region suggested that the resolution of these proteins was also lower.

It is known that phenol extraction gives intense and sharply defined spots [14-16]. Our results were in agreement with such data (Figures $1 \mathrm{~A}$ and $2 \mathrm{~A}$ and Tables 1 and 2).
Densitometric analysis confirmed that phenol extraction produced spots of highest intensity (Table 1). Besides the initial difference in solubility and a large number of steps in phenol extraction method, the final protein content $(2.5 \mathrm{mg} / \mathrm{ml})$ was lower compared to extraction with urea solubilization buffer or direct extraction with IEF buffer. Although most of the polar contaminants were removed, some of phenolic compounds remained present [14-16], causing spots to diffuse. This was especially evident in acidic $\mathrm{pH}$, due to their redox reactions, as reported by Cilia at al. [15]. Also, the lower number of spots (18) compared to thioureaurea extraction (Figures $1 \mathrm{E}$ and $2 \mathrm{E}$ ) could be explained by lower detection of low abundant proteins [17].

Extraction by urea solubilization buffer resulted in high horizontal and vertical streaking in $\mathrm{pH}$ range 3-6, while in $\mathrm{pH}$ range 3-10 spots were less intensive and diffused (Tables 1 and 2).

This was probably due to ionization of urea at acidic $\mathrm{pH}$, which affected isoelectric focusing. Horizontal streaking (Figures $1 \mathrm{C}$ and $2 \mathrm{C}$ ) could be explained by the presence of polar, non-protein (e.g., nucleic acids, phenolic compounds, sugars) contaminants that interfere 


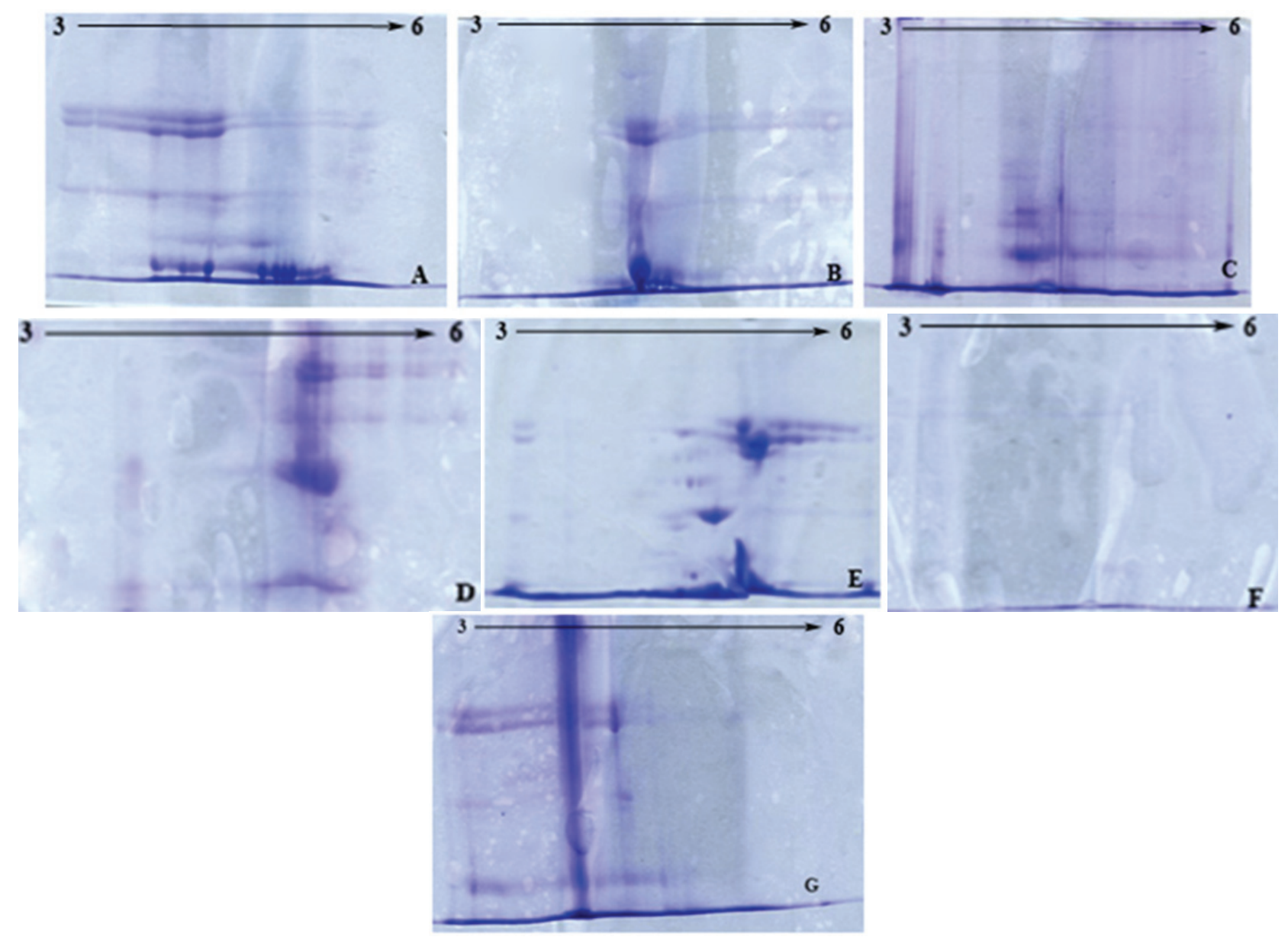

Figure 2. Protein profiles of soybean seed proteins extracted by different extraction methods in pH range 3-6; A) phenol extraction, $B$ ) acetone extraction, C) urea solubilization buffer extraction, D) direct extraction in IEF buffer, E) thiourea-urea extraction, F) extraction with Tris-HCl buffer, G) extraction with Tris-urea buffer.
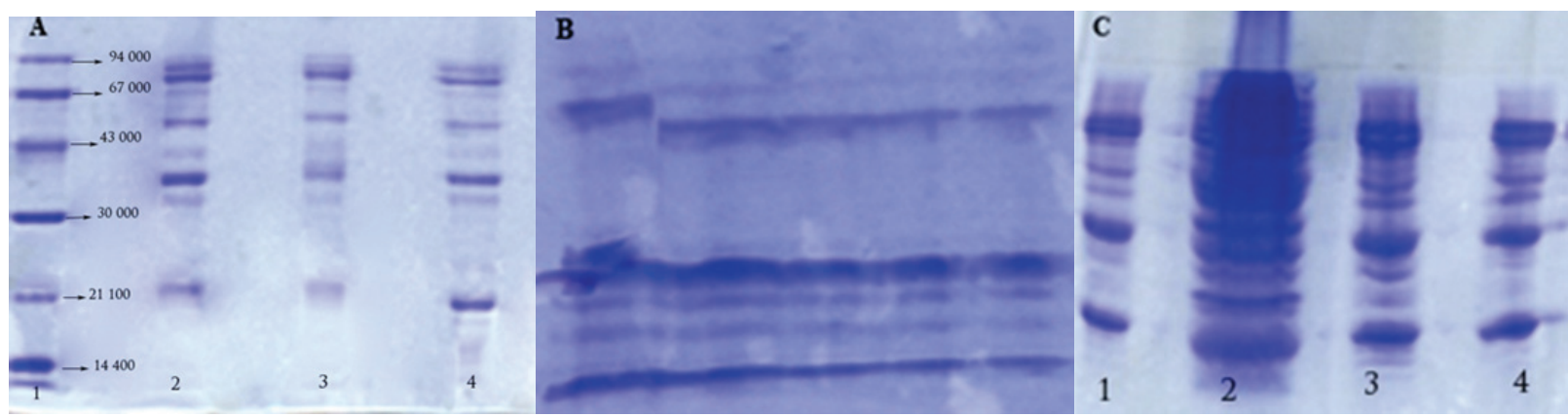

Figure 3. SDS PAGE profiles of soybean proteins obtained by different extraction method. A) Comparison between Tris- $\mathrm{HCl}$ and Tris-urea buffer extraction (1-standards, 2,3-Tris-HCl buffer extraction, Tris-urea buffer extraction). B) Thiourea-urea extraction. C) 1 -Standards, 2 - acetone extraction, 3 - direct extraction in IEF buffer, 4 - extraction with urea solubilization buffer.

with isoelectric focusing. Vertical streaking might be the result of insufficient focusing or carbamoylated proteins. Protein content in extract was $3.1 \mathrm{mg} / \mathrm{ml}$ of sample.

Direct IEF extraction gave similar results as extraction by urea solubilization buffer when number of spots and their intensity were compared (Tables 1 and 2). However, IEF extraction resulted in higher concen- tration of extracted proteins $(3.6 \mathrm{mg} / \mathrm{ml})$, although it might be due to the larger number of contaminants that interfere with the Bradford method, which was used for protein determination. Also, in $\mathrm{pH}$ region 3-10 it gave better results visible in higher number of spots, which could be explained by presence of DTT which favors protein dissociation and suppresses ionization of urea (Figures 1D and 2D). 
Table 1. Intensity of spots (in pixel units) at particular pl range using different extraction methods

\begin{tabular}{|c|c|c|c|c|c|c|}
\hline \multirow{2}{*}{ Extraction method } & \multicolumn{6}{|c|}{ pl Range } \\
\hline & $3-4$ & $4-5$ & $5-6$ & $6-7$ & $7-8$ & $8-9$ \\
\hline Phenol extraction & 7360 & 15776 & 17329 & 3932 & 3790 & 3735 \\
\hline Acetone extraction & 6585 & 12595 & 17203 & 9929 & 8115 & 6585 \\
\hline Direct extraction in IEF buffer & 9287 & 11633 & 11414 & 11799 & 15854 & 5112 \\
\hline Urea buffer extraction & 10130 & 14971 & 11564 & 3956 & 3393 & 2934 \\
\hline Tris- $\mathrm{HCl}$ extraction & 5688 & 7499 & 4940 & 9928 & 7752 & 8020 \\
\hline Tris-urea buffer extraction & 8565 & 17280 & 10521 & 7979 & 6873 & 3578 \\
\hline Thiourea-urea extraction & 10843 & 16971 & 11017 & 9050 & 4697 & 4423 \\
\hline
\end{tabular}

Table 2. Range of molecular weights of proteins present in spots (presented as $10^{3}$ folds) at particular pl range using different extraction methods

\begin{tabular}{|c|c|c|c|c|c|c|}
\hline \multirow{2}{*}{ Extraction method } & \multicolumn{6}{|c|}{ pl Range } \\
\hline & $3-4$ & $4-5$ & $5-6$ & $6-7$ & $7-8$ & $8-9$ \\
\hline Phenol extraction & $11-30$ & $32-76$ & $40-72$ & $15-23$ & $11-27$ & $27-32$ \\
\hline Acetone extraction & $10-32$ & $29-75$ & $42-77$ & $18-25$ & $13-28$ & $28-39$ \\
\hline Direct extraction in IEF buffer & $16-29$ & $33-78$ & $41-73$ & $16-22$ & $14-25$ & $25-34$ \\
\hline Urea buffer extraction & $14-31$ & $35-77$ & $43-71$ & $15-25$ & $13-27$ & $22-31$ \\
\hline Tris- $\mathrm{HCl}$ extraction & $12-30$ & $37-78$ & $44-70$ & $17-24$ & $15-28$ & $23-32$ \\
\hline Tris-urea buffer extraction & $13-32$ & $36-75$ & $45-72$ & $18-27$ & $14-21$ & $24-31$ \\
\hline Thiourea-urea extraction & $10-35$ & $34-77$ & $46-73$ & $17-24$ & $15-27$ & $25-33$ \\
\hline
\end{tabular}

Tris- $\mathrm{HCl}$ buffer extraction gave very small number of spots in acidic $\mathrm{pH}$ region (Figure $2 \mathrm{~F}$ ) while in $\mathrm{pH}$ region 3-10 (Figure 1F) large horizontal streaking was present. Although it was evident from SDS PAGE that Tris extract (Figure 3, A-1) was cleaned from lipid contaminants, the presence of polar contaminants and large concentration of salts prolonged the time of isoelectric focusing. Particularly sensitive to such contamination is the first phase in equilibration of IPG strips that has a role in "cleaning up" strips from salts and other charged molecules. It is possible that by prolonging these steps horizontal streaking would be less prominent, but it could interfere with transferring proteins from strips to gels. Although spots were of low intensity, low-abundant proteins as well as basic subunits could be observed (as confirmed by analysis of molecular weights). Protein content in the extract was 12 $\mathrm{mg} / \mathrm{ml}$.

Tris-urea buffer extraction yields higher content of extracted proteins than Tris- $\mathrm{HCl}$ buffer extraction (15 $\mathrm{mg} / \mathrm{ml}$ ), but large vertical and horizontal streaking, due to insufficient focusing as consequence of charged molecules, prevents precise densitometric analysis (Figures $1 \mathrm{G}$ and $2 \mathrm{G}$ ). Also, probably due to the presence of charged molecules that interfered with electrostatic interactions, better separated subunits were observed, as confirmed by the presence of two additional spots at acidic $\mathrm{pH}$ compared to Tris- $\mathrm{HCl}$ buffer extraction (Figure $2 \mathrm{G}$ and Table 2 ).
Thiourea-urea extraction gave the highest number of intense spots (Table 1). Although spots were less intense than those obtained by phenol extraction, it was possible to simultaneously analyze both more and less abundant proteins (Figures $1 \mathrm{E}$ and $2 \mathrm{E}$ ). These results are in agreement with those reported by Natrajan et al. [14] and Lee et al. [17]. From the analysis of molecular weights, it was evident that proteins were sharply defined, since the number of spots per narrow pl range was the highest (Table 2 ). However, total protein content in extract $(4.6 \mathrm{mg} / \mathrm{ml})$ was lower when compared to Tris-urea buffer extraction and Tris buffer extraction.

\section{CONCLUSION}

Based on the presented results, it can be concluded that the application of Tris- $\mathrm{HCl}$ buffer and Tris-urea buffer for extraction of soybean proteins to be analyzed by 2D electrophoresis is at least questionable. 2D PAGE profiles of this extracts were characterized by low number of spots and high degree of horizontal and vertical streaking. Also, the time needed for completion of isoelectric focusing step was longer than for extracts produced by other extraction methods. It appears that the application of Tris or Tris-urea extraction is limited only to SDS PAGE analysis of soybean proteins. Therefore, it would not be advisable to use the same extract for both types of analysis. Better results could be achieved by prolonging the time of the isoelectric 
focusing step, but this bears the risk of strong incorporation of proteins into the strip, thus causing large horizontal streaking.

Direct extraction in IEF buffer and extraction by urea solubilization buffer gave similar results and were both characterized by low number of diffused spots. Acetone extraction gave low concentration of soluble proteins and high degree of horizontal streaking. Thiourea-urea extraction gave the highest number of less intense protein spots than phenol extraction. Low spot intensity might mean that low abundant proteins could not be analyzed. Phenol extraction consisted of a large number of steps that prolonged the time needed for analysis. However, phenol extraction gave a large number of spots of high intensity. Also, because of a few contaminants present in sample and short time needed for the isoelectric focusing step, there was no horizontal and vertical streaking. Because of its capacity to resolve a high number of intense protein spots, the method of choice would be phenol extraction.

\section{Acknoledgement}

The authors are grateful to the Ministry of Education, Science and Technological Development of the Republic of Serbia for the financial support, project No.: TR 31022.

\section{REFERENCES}

[1] I. Mateos-Aparicio, A. Redondo Cuenca, M. J. Villanueva-Suárez, M.A. Zapata Revilla, Soybean, a promising health source, Nutr. Hosp. 23 (2008) 305-312.

[2] K. Jayakumar, M.M. Azooz, P. Vijayarengan, C. Abdul Jaleel, Biochemical changes with exogenous cobalt application in soybean, J. Phytology 2 (2010) 7-12.

[3] E.B. Cahoon, Genetic enhancement of soybean oil for industrial uses: Prospects and challenge, Ag. Bio Forum 6 (2003) 11-13.

[4] K.L. McCord, W.R. Fehr, T. Wang, G.A. Welke, S.R. Cianzio, S.R. Schnebly, Tocopherol content of soybean lines with reduced linolenate in the seed oil, Crop Sci. $\mathbf{4 4}$ (2004) 772-776.

[5] G. Remondeto, R. Gonzales, M. Anon, Effect of Simultaneous Heat and Reducing Treatments on Some Structural Characteristics of Soy Protein Isolates, Food Sci. Technol. Int. 8 (2002) 223-228.

[6] J.R. Wagner, D.A. Sorgentini, M.C. Anon, Thermal and Electrophoretic behavior, Hidrophobicity and Some Functional properties of Acid Treated Soy Isolates, J. Agric. Food Chem. 44 (1996) 1881-1889.

[7] J.R. Wagner, J. Gueguen, Surface Functional Properties of Native, Acid-Treated and Reduced Soy Glycinin. 2. Emulsifying Properties, J. Agric. Food Chem. 47 (1999) 2181-2187.

[8] M.B. Pešić, B. V. Vucelić-Radović, M.B. Barać, S.P. Stanojević, The influence of genotypic variation in protein composition on emulsifying properties of soy proteins, JAOCS 82 (2005) 667-672.

[9] S. P. Stanojević, M. B. Barać, M. B. Pešić, B. V. Vucelić Radović, Assessment of soy genotype and processing method on quality of soybean tofu, J Agric Food Chem. 59 (2011) 7368-7376.

[10] V.H. Than, K. Shibasaki, Proteins of soybean seeds. A straight forward fractionation and their characterization, J. Agric. Food Chem. 24 (1976) 1117-1121.

[11] K. Yagasaki, T. Takagi, M. Sakai, K. Kitamura, Biochemical Characterization of Soybean protein Consisting of Different Subunits of Glycinin, J. Agric. Food Chem. 45 (1997) 656-660.

[12] F.S. Wu, M.Y. Wang, Extraction of proteins for sodium dodecyl sulfate-polyacrylamide gel electrophoresis from protease-rich plant tissues, Anal. Biochem. 139 (1983) 100-103.

[13] H. Thiellement, M. Zivy, C. Damerval, V. Mechin, Plant proteomics: methods and protocols, Humana Press Inc, Totowa, NJ, 2007, p. 1.

[14] S. Natrajan, C. Xu, T.J. Caperna, W.M. Garret, Comparison of protein solubilization methods suitable for proteomics analysis of soybean seed proteins, Anal. Biochem. 342 (2005) 214-220.

[15] M. Cilia, T. Fish, X. Yang, M. McLaughlin, T.W. Thannhauser, S. Gray,A Comparison of Protein Extraction Methods Suitable for Gel-Based Proteomic Studies of Aphid Proteins, J. Biomol. Tech. 20 (2009) 201-215.

[16] I. S. Sheoran, A. R.S. Ross, D. J. H. Olson, V.K. Sawhney, Compatibility of plant protein extraction methods with mass spectrometry for proteome analysis, Plantsci. 176 (2009) 99-104.

[17] D.G. Lee, N. L. Houston, S.E. Stevenson, G. S. Ladics, S. McClain, L. Privalle, J. J. Thelen, Mass spectrometry analysis of soybean seed proteins: optimization of gelfree quantitative workflow, Anal. Methods 2 (2010) 1577-1583.

[18] M.M. Bradford, A Rapid and Sensitive Method for the Quantitation of Microgram Quantities of Protein Utilizing the Principle of Protein-Dye Binding, Anal.Biochem. 72 (1976) 248-254.

[19] U. Laemmli, Cleavage of Structural Proteins during the Assembly of the Head of Bacteriophage T4, Nature 227 (1970) 680-685.

[20] W.J. Hurkman, C.K. Tanaka, Solubilization of Plant Membrane Proteins for Analysis by Two-Dimensional Gel Electrophoresis, Plant Physiol. 81 (1986) 802-806.

[21] E.M. Herman, R.M. Helm, R. Jung, A.J. Kinney, Genetic modification removes an immunodominant allergen from soybean, Plant Physiol. 132 (2003) 36-43.

[22] K. Gallardo, C. Job, S.P.C. Groot, M. Puype, H. Demol, J. Vanderkerckhove, D. Job, Proteomic Analysis of Arabidopsis Seed Germination and Priming, Plant Physiol. 126 (2001) 835-848.

[23] T. Berkelman, T. Stenstedt, B. Bjellqvist, N. Laird, M. McDowell, I. Olsson, R. Westermeier, 2D Electrophoresis Using Immobilized $\mathrm{pH}$ Gradients: Principles and Methods, Amersham Biosciences, Piscataway, NJ, 1998. 


\title{
IZVOD
}

\section{UTICAJ METODE EKSTRAKCIJE NA PROTEINSKE PROFILE PROTEINA SOJE}

\author{
Milica Ž. Pavlićević, Slađana P. Stanojević, Biljana V. Vucelić-Radović
}

Univerzitet u Beogradu, Poljoprivredni fakultet, Institut za prehrambenu tehnologiju i biohemiju, Katedra za hemiju $i$ biohemiju, Beograd, Srbija

(Naučni rad)

Upoređeni su profili proteina semena soje dobijeni tradicionalnim metodama ekstrakcije (Tris- $\mathrm{HCl}$ puffer i Tris-urea pufer) sa profilima proteina soje ekstrahovanim metodama koje se obično koriste za ekstrakciju biljnih proteina za 2D PAGE analizu (direktno rastvaranje u IEF puferu, acetonska ekstrakcija, fenolna ekstrakcija, ekstrakcija puferom sa ureom i tiourea/urea ekstrakcija). Cilj rada je bio utvrditi primenljivost ekstrakcije Tris-HCl i Tris-urea puferom u 2D PAGE analizi. Raširena primena ove dve metode ekstrakcije zasnovana je na dobijanju visoke koncentracije proteina koji se karakterišu dobrom rastvorljivošću, kao i na već dobro poznatim $\mathrm{Rf}$ vrednostima pojedinih proteinskih podjedinica na SDS PAGE elektroforegramima visoke rezolucije. Tako bi njihova eventualna primena u proteomiks analizama, omogućila kako brzu analizu uzoraka, tako i prikupljanje većeg broja podataka, jer bi se izbegla potreba za resolubilizacijom i gubitak proteina. Poređenje ekstrakcionih metoda vršeno je na osnovu broja rastvornih proteina u ekstraktu, kao i denzitometrijskih merenja broja, intenziteta i oštrine tačaka na $2 \mathrm{D}$ profilima u okviru dva različita $\mathrm{pH}$ opsega. Premda ekstrakcije sa Tris- $\mathrm{HCl}$ i Tris-urea puferom daju najveću koncentraciju proteina u ekstraktu, ove metode daju manji broj tačaka u poredjenju sa ostalim ispitivanim metodama. Takođe, izraženo vertikalno i horizontalno "razvlačenje" onemogućavaju preciznu denzitometrijsku analizu. Dodatni nedostatak ovih metoda (pogotovu ekstrakcije sa Tris-HCl puferom) jeste produženo vreme potrebno za korak izoelektričnog fokusiranja u poredjenju sa ostalim metodama. Direktna ekstrakcija u IEF puferu i ekstrakcija puferom sa ureom daju slične rezultate i karakterišu se malim brojem difuznih tačaka. Acetonskom ekstrakcijom dobija se mala koncentracija rastvorljivih proteina, a na 2D PAGE profilima uočava se visok stepen horizontalnog razvlacenja. Tiourea-urea ekstrakcija daje veći broj manje intenzivnih tačaka u poređenju sa fenolnom ekstrakcijom. Manji intenzitet tačaka može značiti gubitak manje zastupljenih proteina. U slučaju fenolne ekstrakcije, veliki broj koraka tokom pripreme uzorka produžava vreme analize, ali su tačke najintenziivnije. Na osnovu dobijenih rezultata, zaključeno je da je fenolna ekstrakcija metoda izbora za ekstrakciju proteina iz semena soje za analizu 2D PAGE metodom.
Ključne reči: Sojini proteini • 2D PAGE analiza • Ekstrakcija • Denzitometrija • Izoelektrično fokusiranje 